\title{
Satellite observations of Mexico City pollution outflow from the Tropospheric Emissions Spectrometer (TES)
}

\author{
Changsub Shim ${ }^{\mathrm{a}, *}$, Qinbin $\mathrm{Li}^{\mathrm{a}, \mathrm{b}}$, Ming Luo ${ }^{\mathrm{a}}$, Susan Kulawik ${ }^{\mathrm{a}}$, Helen Worden ${ }^{\mathrm{c}}$, John Worden ${ }^{\mathrm{a}}$, \\ Annmarie Eldering ${ }^{\mathrm{a}}$, Glenn Diskin ${ }^{\mathrm{d}}$, Glen Sachse ${ }^{\mathrm{d}}$, Andy Weinheimer ${ }^{\mathrm{c}}$, David Knapp ${ }^{\mathrm{c}}$, \\ Deedee Montzca ${ }^{\mathrm{c}}$, Teresa Campos ${ }^{\mathrm{c}}$ \\ aet Propulsion Laboratory, California Institute of Technology, CA, USA \\ ${ }^{\mathrm{b}}$ Department of Atmospheric and Oceanic Sciences, University of California, Los Angeles, CA, USA \\ ${ }^{\mathrm{C}}$ National Center for Atmospheric Research (NCAR), CO, USA \\ ${ }^{\mathrm{d}}$ NASA Langley Research Center, VA, USA
}

\section{A R T I C L E I N F O}

\section{Article history:}

Received 23 July 2008

Received in revised form

28 October 2008

Accepted 12 November 2008

\section{Keyword:}

Mega-city pollution

TES

$\mathrm{O}_{3}-\mathrm{CO}$ correlation

INTEX-B

Mexico city

\begin{abstract}
A B S T R A C T
Concurrent tropospheric $\mathrm{O}_{3}$ and $\mathrm{CO}$ vertical profiles from the Tropospheric Emission Spectrometer (TES) during the MILAGRO/INTEX-B aircraft campaigns over the Mexico City Metropolitan Area (MCMA) and its surrounding regions were used to examine Mexico City pollution outflow on a regional scale. The pollution outflow from the MCMA occurred predominantly at $600-800 \mathrm{hPa}$ as evident in $\mathrm{O}_{3}, \mathrm{CO}$, and $\mathrm{NO}_{x}$ enhancements in the in situ aircraft observations. TES $\mathrm{O}_{3}$ and $\mathrm{CO}$ are sensitive to the MCMA pollution outflow due to their relatively high sensitivities at $600-800 \mathrm{hPa}$. We examined $\mathrm{O}_{3}, \mathrm{CO}$, and their correlation at 600-800 hPa from TES retrievals, aircraft measurements, and GEOS-Chem model results. TES captures much of the spatial and day-to-day variability of $\mathrm{O}_{3}$ seen in the in situ data. TES CO, however, shows much less spatial and day-to-day variability compared with the in situ observations. The $\Delta \mathrm{O}_{3} / \Delta \mathrm{CO}$ slope is significantly higher in the TES data (0.43) than the in situ data $(0.28)$ due partly to the lack of variability in TES CO. Extraordinarily high $\Delta \mathrm{O}_{3} / \Delta \mathrm{CO}$ slope $(0.81)$ from TES observations at $618 \mathrm{hPa}$ over the Eastern U.S. was previously reported by Zhang et al. [Zhang, L., Jacob, D.J., Bowman, K.W., et al., 2006. Ozone-CO correlations determined by the TES satellite instrument in continental outflow regions. Geophys. Res. Lett. 33, L18804. 10.1029/2006GL026399.]. Thus the application of TES $\mathrm{CO}_{-} \mathrm{O}_{3}$ correlation to map continental pollution outflow needs further examination.
\end{abstract}

Published by Elsevier Ltd.

\section{Introduction}

Mega-city pollution has been a major environmental concern in developing and developed countries alike (Fuchs et al., 1994). Pollution from these mega-cities has grave implications on regional to global air quality and climate change (Mage et al., 1996; Molina and Molina, 2004). One of the world's most densely populated mega-cities, the Mexico City Metropolitan Area (MCMA: $\sim 19^{\circ} \mathrm{N}$, $\sim 99^{\circ} \mathrm{W}, \sim 750 \mathrm{hPa}$ ), with a population of over 19 million within an area of $\sim 1500 \mathrm{~km}^{2}$, is among the most polluted cities (IPCC, 2007). Large emissions of air pollutants from the MCMA result from pervasive incomplete combustion including low-temperature

\footnotetext{
* Correspondence author. Jet Propultion Laboratory, M/S 183-501, 4800 Oak Grove Drive, Pasadena, CA 91109-8099, USA. Tel.: +1 818354 4833; fax: +1 818354 5148.

E-mail address: cshim@jpl.nasa.gov (C. Shim).
}

household cooking and heating and from vehicle emissions (CAM, 2001). In 1998, for example, the total volatile organic compounds (VOCs) emissions from the MCMA (475 Gg/yr) is higher than that from Los Angeles (362 Gg/yr in 2001), the most polluted mega-city in the United Sates (Molina and Molina, 2002). The MCMA is located in the Valley of Mexico, a large basin in the high plateaus at the center of Mexico, at an altitude of $2.2 \mathrm{~km}$ above sea level, surrounded by mountains on all four sides except a small opening at the north. The basin is often under the influence of high pressure systems, whose weak winds and persistent boundary layer thermal inversions often trap pollution to within the basin (Molina and Molina, 2002).

The MILAGRO/INTEX-B aircraft campaigns in March 2006 aimed to investigate the emissions, transport, and physiochemical transformation of key air pollutants from the MCMA (www.joss.ucar. edu/milagro/; Singh et al., submitted). During this campaign, the synoptic scale export of the MCMA pollution out of the Valley of Mexico is generally controlled by thermal-driven circulations in the 
boundary layer and southwesterly wind in the middle troposphere (Fast et al., 2007). Airborne measurements of various gaseous and aerosol pollutants were made aboard the NASA DC-8 and NSF C-130 aircrafts. In coordination with the aircraft observations, the Tropospheric Emission Spectrometer (TES) instrument aboard the Aura satellite conducted several special observations and global surveys (see Section 2.2) during the campaigns. TES provides concurrent global three-dimensional (3-D) mapping of tropospheric $\mathrm{O}_{3}$ and $\mathrm{CO}$ (Beer, 2006).

Some recent studies have explored the use of space-borne observations to examine regional to global air pollution (Boersma et al., 2008; Clerbaux et al., 2008; Massie et al., 2006; Zhang et al., 2006). For example, Zhang et al. (2006) has shown that TES tropospheric data can be used to map global pollution and continental outflow. They found positive $\mathrm{O}_{3}-\mathrm{CO}$ correlations and slopes $\left(\Delta \mathrm{O}_{3} / \Delta \mathrm{CO}\right)$ at $618 \mathrm{hPa}$ over continental outflow regions, indicating significant photochemical $\mathrm{O}_{3}$ production from pollution. In this study, we intend to examine TES observations of pollution outflow from the MCMA during MILAGRO/INTEX-B. The in situ aircraft observations allow us to evaluate TES $\mathrm{O}_{3}$ and $\mathrm{CO}$ retrievals, in particular the spatial and day-to-day variability, and $\mathrm{O}_{3}-\mathrm{CO}$ correlations. $\mathrm{CO}$ is a good tracer for industrial and biomass burning pollution (Logan et al., 1981). The $\mathrm{O}_{3}-\mathrm{CO}$ relationship, among other tracer-tracer correlations, has been used for ozone source attribution. It provides a reliable characterization of continental pollution outflow (Fishman and Seiler, 1983; Chameides et al., 1987; Parrish et al., 1993). Additionally, the $\mathrm{O}_{3}-\mathrm{CO}$ correlation has also been used to evaluate the photochemical $\mathrm{O}_{3}$ production in chemical transport models (Chin et al., 1994).

We examine TES $\mathrm{O}_{3}$ and $\mathrm{CO}$ and their correlations over the MCMA and surrounding regions against the aforementioned in situ aircraft observations. In particular, we focus on the spatial and temporal variability and $\Delta \mathrm{O}_{3} / \Delta \mathrm{CO}$ enhancement ratio. Results from the GEOS-Chem global 3-D chemical transport model are also compared with both the TES data and aircraft observations. We describe the aircraft measurements, TES retrievals, and GEOS-Chem in Section 2. Time series of $\mathrm{O}_{3}$ and $\mathrm{CO}$ and $\mathrm{O}_{3}-\mathrm{CO}$ correlations are discussed in Section 3. Conclusions are given in Section 4.

\section{Methodology}

\subsection{Aircraft measurements}

A suite of chemical tracers including $\mathrm{O}_{3}, \mathrm{CO}, \mathrm{NO}_{x}$, and VOCs were measured aboard the C-130 and DC-8 during the MILAGRO/INTEX-
B campaigns. Fig. 1 (left panel) shows the aircraft flight tracks. The C-130 flights stayed closer to the MCMA compared with those of the DC-8 with the later covering a much larger domain. $\mathrm{O}_{3}$ and $\mathrm{CO}$ were measured by ChemiLuminescence Detector (CLD) and Tunable Diode Laser (TDL), respectively (Avery et al., 2001; Madronich et al., 2004; Sachse et al., 1987) on the both C-130 and DC- 8 . The precisions of $\mathrm{O}_{3}$ and $\mathrm{CO}$ are $3-7 \%$ and $1 \%$, respectively with $\pm 5 \%$ accuracy (Richards et al., 2008; Sachse et al, 1987; Singh et al., submitted). We used the 1-minute merged data. Our analysis focuses on observations from March 4-31, 2006 within $15^{\circ} \mathrm{N}-25^{\circ} \mathrm{N}$ and $95^{\circ} \mathrm{W}-103^{\circ} \mathrm{W}$ (rectangle, Fig. 1).

\subsection{TES data}

TES measures infrared emissions with high spectral resolution $\left(0.1 \mathrm{~cm}^{-1}\right)$ and a wide spectral range from 660 to $2260 \mathrm{~cm}^{-1}$ (Beer et al., 2001). TES overpass times (ascending node) are 01:45 and 13:45 local time. TES has a footprint of $\sim 5 \times 8 \mathrm{~km}$ in nadir, about $180 \mathrm{~km}$ apart between consecutive measurements along the orbital tracks in the standard Global Survey mode. Global coverage is achieved in 16 days. In the Step and Stare special observation mode, TES provides denser nadir spatial coverage ( $\sim 40 \mathrm{~km}$ apart between consecutive measurements along the orbit) over a $60^{\circ}$ latitudinal range (Beer, 2006). We use here $\mathrm{O}_{3}$ and $\mathrm{CO}$ data from all eight Step and Stares and four global surveys from March 2006. The corresponding TES orbital tracks over the MCMA region during MILAGRO/INTEX-B are shown in Fig. 1 (right panel).

TES retrievals of $\mathrm{O}_{3}$ and $\mathrm{CO}$ are based on the optimization between modeled $a$ priori and observed radiance with maximum a posteriori method (Rogers, 2000) and the details of the retrieval algorithms are described in Worden et al. (2004), Bowman et al. (2002, 2006), and Luo et al. (2007a). Here we use the version 3 data (V003, F04_04) (Osterman et al., 2006) available at the time of this study. The degrees of freedom for signal (DOFs) for $\mathrm{O}_{3}$ and $\mathrm{CO}$ are 1.6 and 1.4, respectively in the troposphere (Worden et al., 2004; Bowman et al., 2006; Luo et al., 2007b). TES sensitivity is reduced by $\sim 40 \%$ with a cloud optical depth of 0.1 in the lower troposphere (Kulawik et al., 2006). We excluded TES retrievals when cloud optical depth is larger than 0.2 .

The validation of TES data with in situ measurements requires applying TES averaging kernels to in situ profiles to take into account the relatively coarse TES vertical resolution and $a$ priori information (Rodgers and Connor, 2003; Worden et al., 2007). On average, TES $\mathrm{O}_{3}$ shows a positive bias of $\sim 6 \mathrm{ppbv}$ (15\%) throughout the troposphere in comparison with ozonesonde data (Nassar et al.,
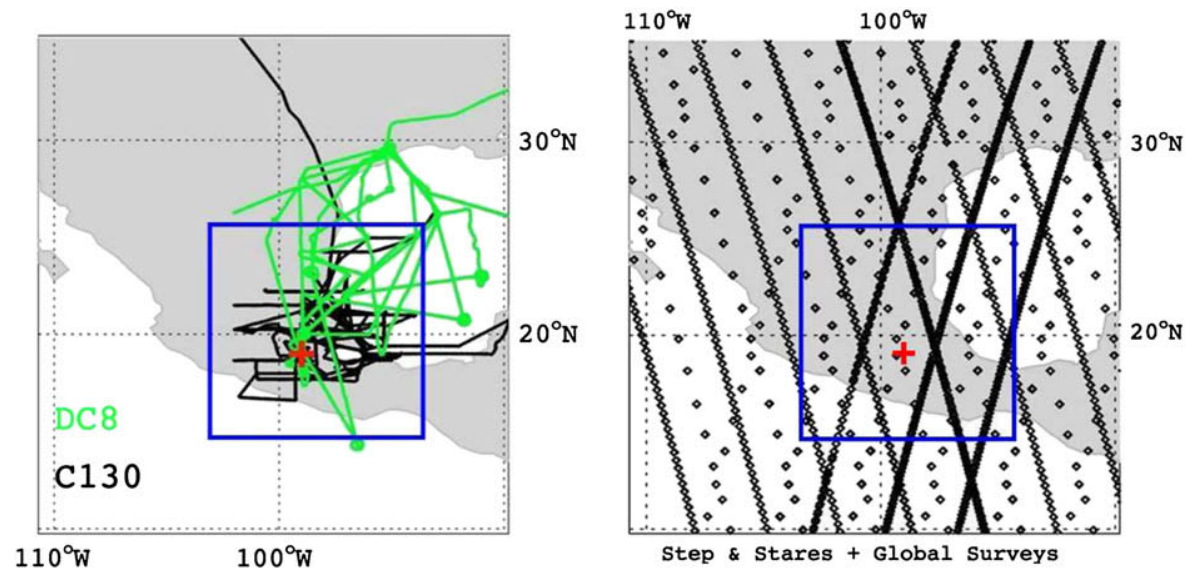

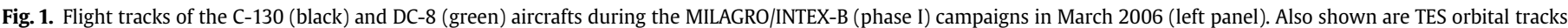

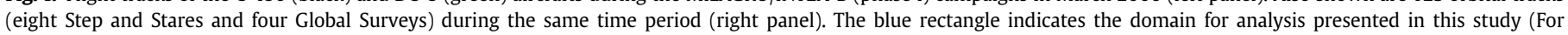
interpretation of the references to color in this figure legend, the reader is referred to the web version of this article). 
2008; Worden et al., 2007). Richards et al. (2008) compared TES $\mathrm{O}_{3}$ data with airborne in situ measurements during INTEX-B and found a positive bias of $\sim 2-6$ ppbv (5-15\%) in the troposphere. TES CO has been validated with aircraft data during the Aura Validation Experiments (AVEs) by Lopez et al. (2008). They found that TES CO is slightly lower than the in situ data ( $<10 \%$ or $\sim 8 \mathrm{ppbv})$ in the middle latitudes and slightly higher $(5-10 \%$ or $\sim 4-8$ ppbv) in the tropics. Luo et al. (2007b) conducted TES CO validations during INTEX-B and showed consistent results (a negative bias of $<10 \%$ ). Due to the lack of concurrent TES and in situ measurements, relaxed coincident criteria such as within $\sim 600 \mathrm{~km}$ distance and $\sim 48 \mathrm{~h}$ were used in the aforementioned validations.

Fig. 2 shows the closest TES orbital track (a Global Survey) to MCMA on March 19th, 2006 (left panel) and averaging kernels for $\mathrm{O}_{3}$ and $\mathrm{CO}$ (upper and lower right panels) along the orbital track between $15^{\circ} \mathrm{N}$ and $25^{\circ} \mathrm{N}$ over Mexico. The closest distance between the MCMA and this TES orbital track is $95 \mathrm{~km}$ at location "a" (Fig. 2) over the Mexico City Basin $\left(\sim 20^{\circ} \mathrm{N}, \sim 750 \mathrm{hPa}\right)$ where there is relatively poor sensitivity for both $\mathrm{O}_{3}$ and $\mathrm{CO}$. The reason for the weak sensitivity is under further investigation by the TES retrieval team (K. Bowman, personal communication, 2008, Jet Propulsion Laboratory). By contrast, $\mathrm{O}_{3}$ and $\mathrm{CO}$ averaging kernels away from the Mexico City Basin ( $23.3^{\circ} \mathrm{N}, \sim 850 \mathrm{hPa}$; location "b" in Fig. 2) show largest sensitivities to $600-800 \mathrm{hPa}$, typical for the middle and low troposphere under clear sky (e.g., Jones et al., 2003; Luo et al., 2007a; Richards et al., 2008; Worden et al., 2007; Zhang et al., 2006).

To illustrate the latitudinal variations of TES $\mathrm{O}_{3}$ and $\mathrm{CO}$ averaging kernels, the diagonals of the $\mathrm{TES}_{3}$ and $\mathrm{CO}$ averaging kernels from the March 12th TES Step and Stares are shown in Fig. 3 for $5^{\circ} \mathrm{S}-35^{\circ} \mathrm{N}$. The closest distance from the orbital track to the MCMA is $\sim 150 \mathrm{~km}$. While there is relatively large sensitivity in the lower to middle troposphere, there is poor sensitivity for both $\mathrm{O}_{3}$ and $\mathrm{CO}$ over the Mexico City Basin $\left(17^{\circ} \mathrm{N}-20^{\circ} \mathrm{N}\right)$. Thus it appears that TES data are sensitive to the MCMA pollution outflow, rather than the pollution right over Mexico City Basin itself.

\subsection{GEOS-Chem}

GEOS-Chem is a global 3-D chemical transport model driven by assimilated meteorological data from NASA Global Modeling
Assimilation Office (GMAO) (Bey et al., 2001). We use version 7-0410 (http://www.as.harvard.edu/chemistry/trop/geos) of the model, driven by GEOS-4 meteorological data with a horizontal resolution of $2^{\circ} \times 2.5^{\circ}$ and 30 vertical layers. The meteorological fields are updated every six hours, and the surface fields and mixing depths are updated every three hours.

GEOS-Chem includes a comprehensive tropospheric $\mathrm{O}_{3}-\mathrm{NO}_{x^{-}}$ VOC chemistry mechanism. Climatological monthly mean biomass burning emissions are from Duncan et al. (2003). The fossil fuel emissions are from the Emission Database for Global Atmospheric Research (EDGAR) inventory for $\mathrm{NO}_{x}, \mathrm{CO}$, and $\mathrm{SO}_{2}$ and from the Global Emission Inventory Activity (GEIA) for other chemical compounds (Benkovitz et al., 1996; Olivier and Berdowski, 2001). These emissions are updated with particular national emission inventories and fuel use data: the Big Bend Regional Aerosol and Visibility Observational Study (BRAVO) inventory for Mexico (Kuhns et al., 2005) and U.S. EPA NEI 99 inventory (National Emissions Inventory, base year 1999, version 3) for the continental U.S. (EPA, 2004). The biogenic VOCs emissions are based on the Model of Emissions of Gases and Aerosols from Nature (MEGAN) inventory (Guenther et al., 2006). The lightning $\mathrm{NO}_{x}$ emissions are parameterized based on cloud top height and regionally scaled to climatological satellite observations of flash rates (Hudman et al., 2007). We conducted GEOS-Chem simulations for September 2005-March 2006 with the first six months for initialization. We focus our analysis on March 2006. Model results are sampled along the aircraft flight tracks and TES orbital tracks.

To compare GEOS-Chem results with TES retrievals, model profiles of $\mathrm{O}_{3}$ and $\mathrm{CO}$ are convoluted with TES averaging kernels to account for the different sensitivities and a priori information of TES retrievals to different pressure levels (Jones et al., 2003; Richards et al., 2008). The resulting model profiles can then be directly compared with TES retrievals (Zhang et al., 2006; Jourdain et al., 2007; Worden et al., 2007).

We note here that the emissions used in our GEOS-Chem simulations are not 2006-specific. Additionally, the horizontal resolution of $2^{\circ} \times 2.5^{\circ}$ may be too coarse for resolving details of the regional pollution outflow. GEOS-Chem simulations with $1^{\circ} \times 1^{\circ}$ nested simulations over North America have been done before (e.g., Li et al., 2005) but not available for 2006 at the time of this study.
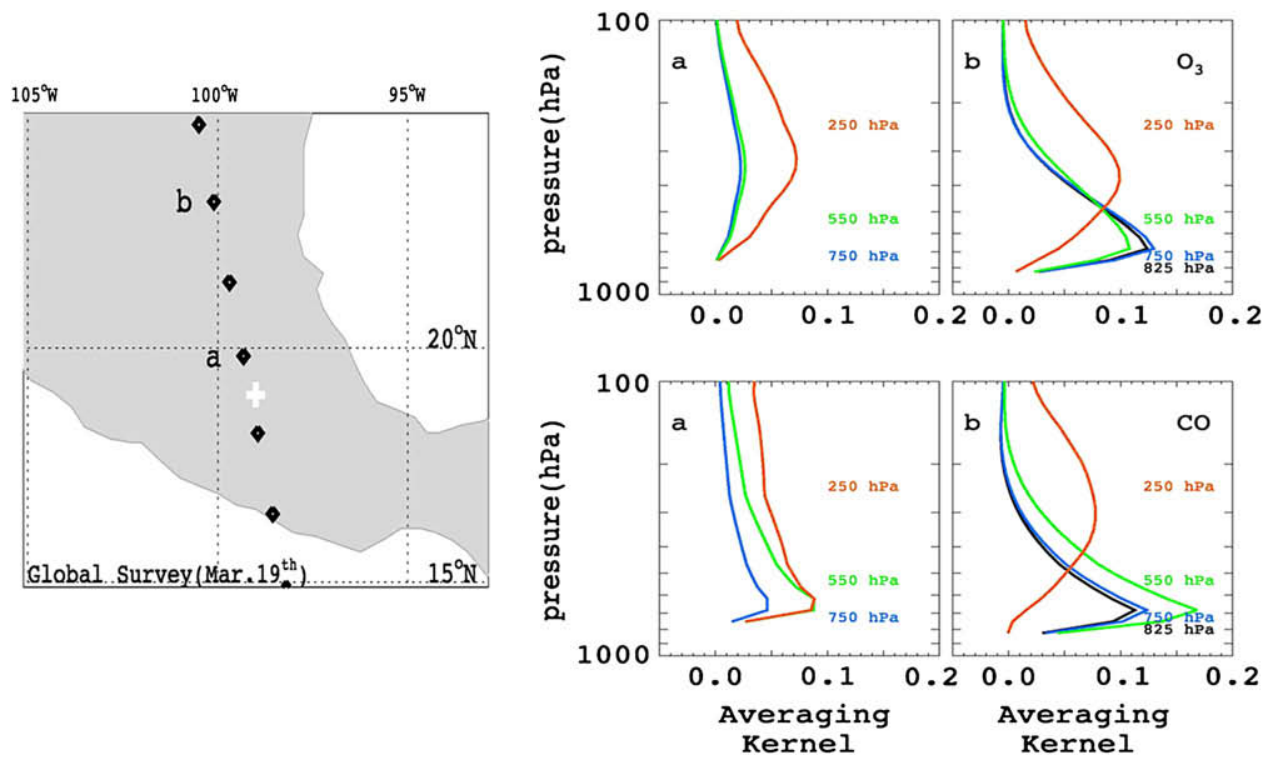

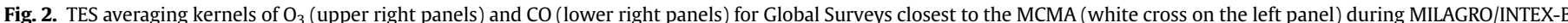

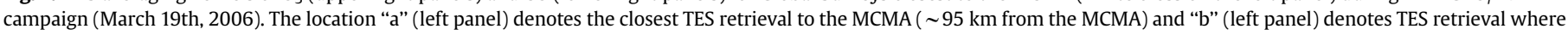
its distance is $\sim 470 \mathrm{~km}$ from the MCMA. Averaging kernels for different pressure levels are colorcoded. 
TES Nadir Averaging Kernel Diagonals

$\mathrm{CO}$

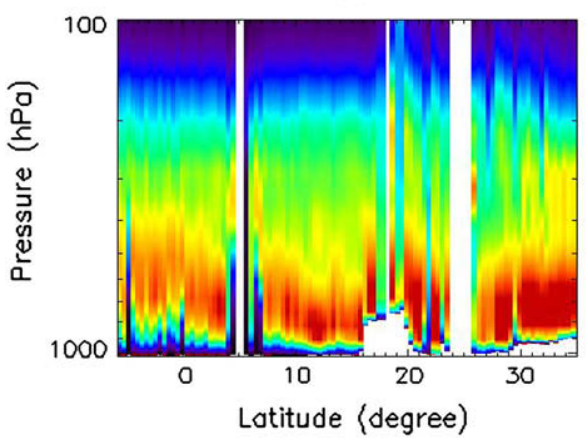

Ozone

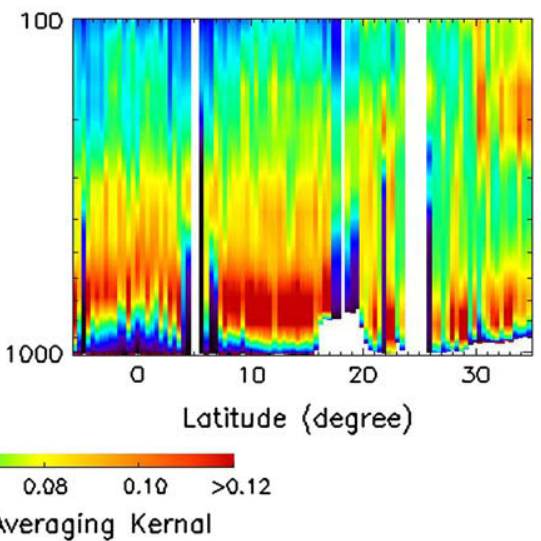

Fig. 3. The TES Nadir Averaging Kernel Diagonals for $\mathrm{CO}$ (left) and $\mathrm{O}_{3}$ (right) along the special observations in Fig. 2 .

We include GEOS-Chem results for comparison despite the aforementioned shortcomings in our model simulations. Improving model simulations for the MILAGRO/INTEX-B period is obviously required to understand the processes controlling the MCMA outflow. It is however beyond the scope of the present analysis.

\section{Results and discussions}

\subsection{Mexico City pollution outflow}

The median vertical profiles of $\mathrm{O}_{3}, \mathrm{CO}$, and $\mathrm{NO}_{x}$ mixing ratios from the aircraft measurements during MILAGRO/INTEX-B are shown separately for DC-8 and C-130 in Fig. 4. Data points below the $800 \mathrm{hPa}$ pressure level were from observations at lower altitudes further away from the high-elevation MCMA. Values shown in Fig. 4 are binned every $50 \mathrm{hPa}$ vertically. The $\mathrm{NO}_{x}$ profiles are shown here in addition to $\mathrm{O}_{3}$ and $\mathrm{CO}$ for the purpose of indicating the altitude range for the MCMA pollution outflow. The outflow occurs mainly at $600-800 \mathrm{hPa}$, corresponding to the high elevation of the Mexico City Basin ( $750 \mathrm{hPa})$, as indicated by the enhanced $\mathrm{O}_{3}, \mathrm{CO}$, and $\mathrm{NO}_{x}$ levels.

There are generally higher concentrations for all three pollutants, $\mathrm{O}_{3}, \mathrm{CO}$, and $\mathrm{NO}_{x}$ at $500-800 \mathrm{hPa}$ in the $\mathrm{C}-130$ observations than those from the DC- 8 , while the later shows higher concentrations at 700-900 hPa. The higher concentrations in the C-130 observations at $500-800 \mathrm{hPa}$ are due presumably to the proximity of the C-130 flights to the urban area of the MCMA (Fig. 1) thus exposure to more pollution events. The higher concentrations in the DC- 8 observations at 700-900 hPa likely indicate the export of the MCMA pollution by the prevailing southwesterlies in the middle troposphere to downwind regions (e.g., near the Gulf of Mexico) where there is more DC- 8 coverage, followed by subsidence (Fast et al., 2007).

As stated in the Section 2.2, TES averaging kernels were applied to in situ profiles for direct comparisons in previous TES validation studies with relaxed coincidence criteria. However, such coincidence criteria are generally inappropriate for a relatively small regional domain such as the one used in the present analysis (rectangle, Fig. 1). During MILAGRO/INTEX-B there is only one coincident spiral profiling by the DC-8 for TES validation on March 12 th $\left(23^{\circ} \mathrm{N}\right.$ and $98.5^{\circ} \mathrm{W}, \sim 450 \mathrm{~km}$ away from the MCMA). Validation results using the profiles from that spiral have been reported by Richards et al. (2008) and Luo et al. (2007b) and those were cited in Section 2.2. In general, direct comparisons of absolute mixing ratios between TES and in situ data over the MCMA and its surrounding regions can be challenging primarily because of the scarcity of coincident TES and aircraft profiles. We instead intend to investigate the spatial and temporal variabilities of $\mathrm{O} 3$ and $\mathrm{CO}$ and the O3-CO correlation as seen from TES and in situ data and GEOSChem results.
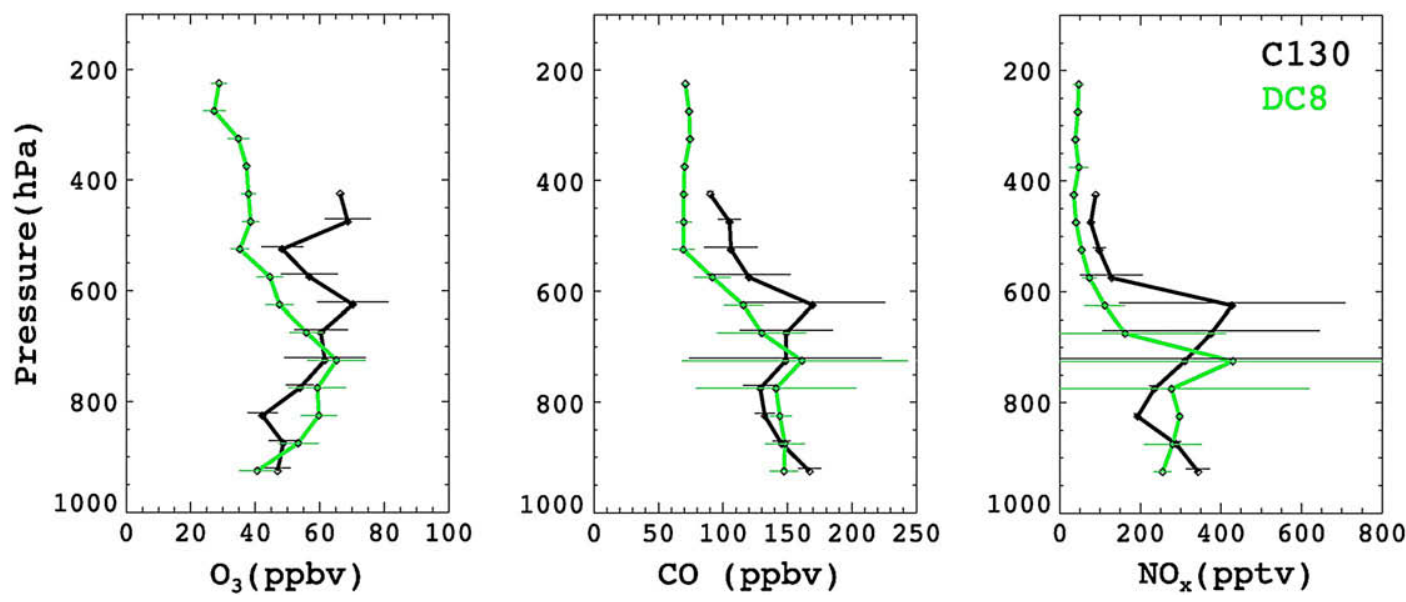

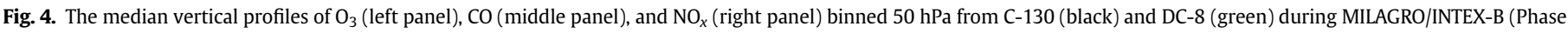

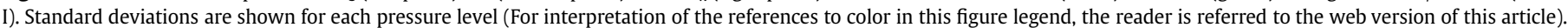




\subsection{Vertical distributions of TES tropospheric $\mathrm{O}_{3}$ and $\mathrm{CO}$ over the $M C M A$}

Fig. 5 shows individual TES vertical $\mathrm{O}_{3}$ profile during MILAGRO/ INTEX-B (gray dots) within the domain defined in Fig. 1. The median TES vertical $\mathrm{O}_{3}$ profile is also shown (data binned every $50 \mathrm{hPa}$ ). We focus our analysis on the 600-800 hPa pressure levels where most of the MCMA outflow occurs (Fig. 4). Large enhancements and variations in $\mathrm{O}_{3}$ are seen in several profiles. Such enhancements are not seen in the TES a priori (not shown). In addition, the mean DOFs is greater than 0.4 at $600-900 \mathrm{hPa}$, indicating that the TES $\mathrm{O}_{3}$ profiles are not entirely determined by the $a$ priori. Fig. 6 shows the corresponding individual and monthly median vertical profiles of TES CO. Several profiles with enhanced CO concentrations at $500-800 \mathrm{hPa}$ (>130 ppbv) are not seen in the a priori (not shown).

Also shown in Figs. 5 and 6, TES $\mathrm{O}_{3}$ and $\mathrm{CO}$ profiles over unpolluted regions over the tropical Pacific adjacent to the west coast of Mexico $\left(103^{\circ} \mathrm{W}-107^{\circ} \mathrm{W}, 15^{\circ} \mathrm{N}-25^{\circ} \mathrm{N}\right.$, black dots in Figs. 5 and 6). The notably enhanced concentrations ( $>70 \mathrm{ppbv}$ for $\mathrm{O}_{3}$ and $>130$ ppbv for $\mathrm{CO}$, indicated by the gray dots) are only seen in the profiles over the MCMA and its downwind regions. This indicates that TES captures the enhancements in $\mathrm{O}_{3}$ and $\mathrm{CO}$ on a regional scale as a result of the MCMA pollution outflow.

Fig. 7 shows the zonal mean of TES $\mathrm{O}_{3}$ and $\mathrm{CO}$ in March 2006 over the domain defined in Fig. 1 (rectangle). TES does not clearly show the pollution over the Mexico City Basin $\left(\sim 19^{\circ} \mathrm{N}\right)$ due mainly to the retrieval issues (see Section 2.2). The enhanced TES $\mathrm{O}_{3}$ and CO between $20^{\circ} \mathrm{N}$ and $23^{\circ} \mathrm{N}$ is likely due in part to the MCMA pollution outflow transported by the southwesterly. This pattern is seen in TES data from other years (not shown).

\section{3. $\mathrm{O}_{3}$ and $\mathrm{CO}$ variabilities over the MCMA}

Our analysis in this Section focuses on the variabilities of lower tropospheric $\mathrm{O}_{3}$ and $\mathrm{CO}$ and to what degree they are captured by

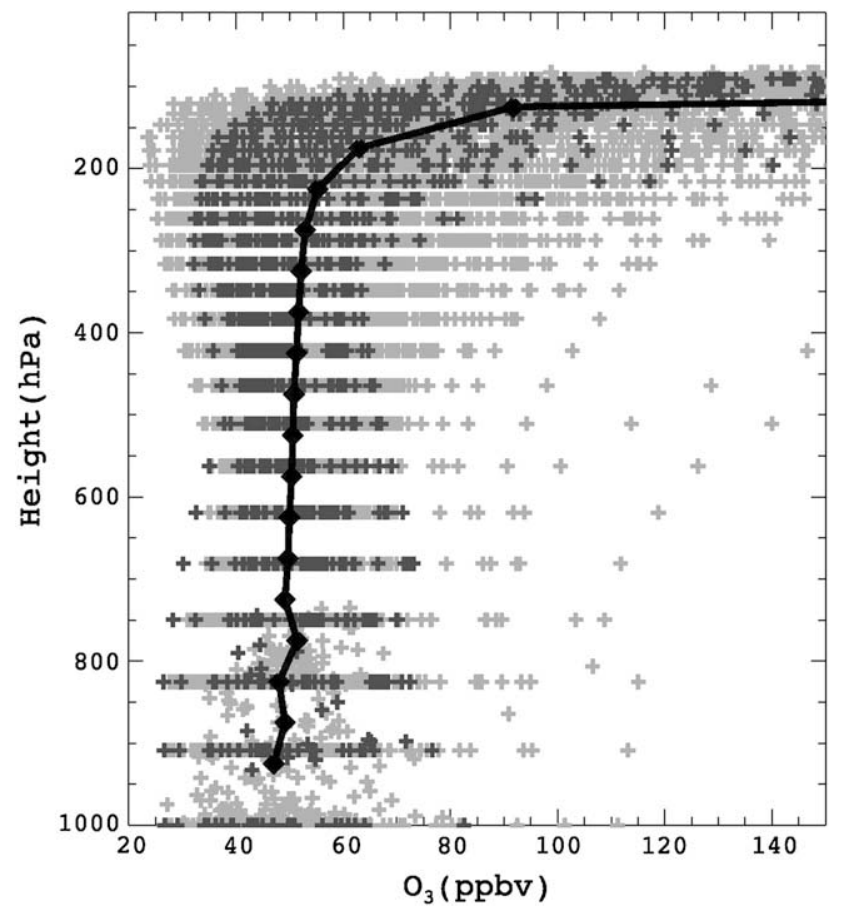

Fig. 5. The collected TES vertical profiles of $\mathrm{O}_{3}$ (gray dots) over the MCMA and surrounding regions $\left(15^{\circ} \mathrm{N}-25^{\circ} \mathrm{N}\right.$ and $\left.95^{\circ} \mathrm{W}-103^{\circ} \mathrm{W}\right)$ in March 2006 . The black dots indicate the vertical profiles over the unpolluted region $\left(15^{\circ} \mathrm{N}-25^{\circ} \mathrm{N}\right.$ and $103^{\circ} \mathrm{W}-$ $\left.107^{\circ} \mathrm{W}\right)$. The black solid line indicates the median profiles binned $50 \mathrm{hPa}$.

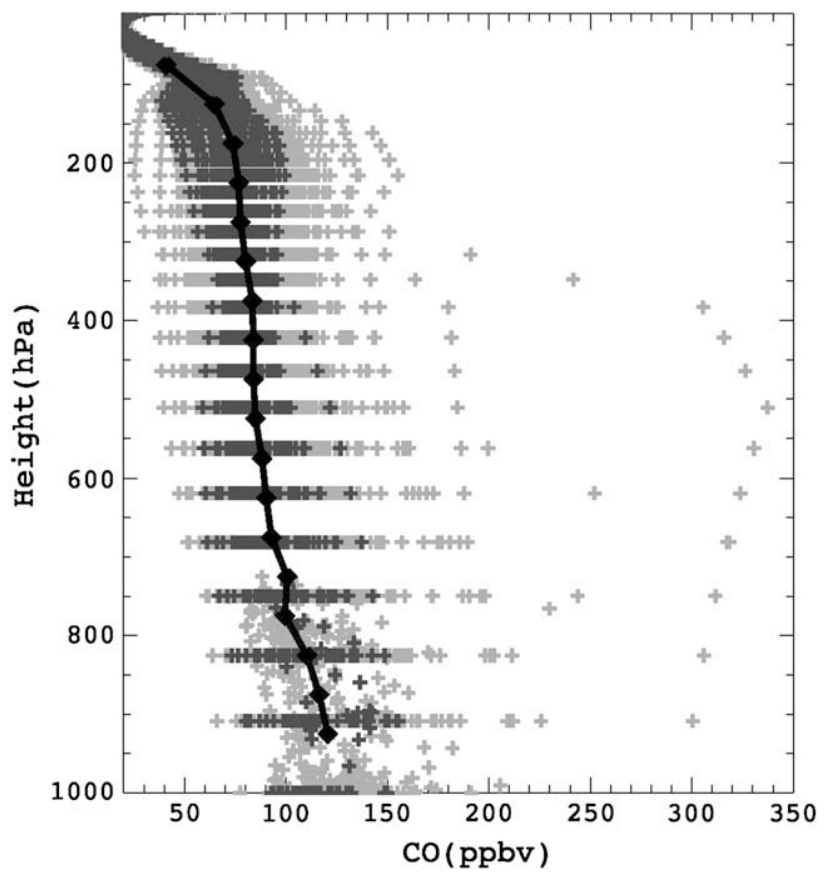

Fig. 6. Same as Fig. 5, but for CO.

TES observations. More specifically, we examine the day-to-day and spatial variabilities of $\mathrm{TES}_{3}$ and $\mathrm{CO}$ in comparison with the in situ observations. Fig. 8 shows time series of $\mathrm{O}_{3}$ and $\mathrm{CO}$ from the in situ aircraft observations and TES retrievals during MILAGRO/INTEX-B. Values shown are for $600-800 \mathrm{hPa}$. The in situ data are shown without applying TES averaging kernels for reasons discussed in Section 3.1. GEOS-chem model results are also shown without TES averaging kernels applied. On average the application of TES averaging kernels to GEOS-Chem concentration fields makes little difference: $<1$ ppbv for $\mathrm{O}_{3}$ and $<6$ ppbv for $\mathrm{CO}$, respectively. We emphasize here that Fig. 8 is intended for examining spatial and temporal varibilities of $\mathrm{O}_{3}$ and $\mathrm{CO}$ instead of their absolute magnitudes among the three data sets.

The in situ data in Fig. 8 indicate nine strong pollution days: March 4th, 8th, 10th, 11th, 12th, 16th, 19th, 22nd, and 29th with $\mathrm{O}_{3}$
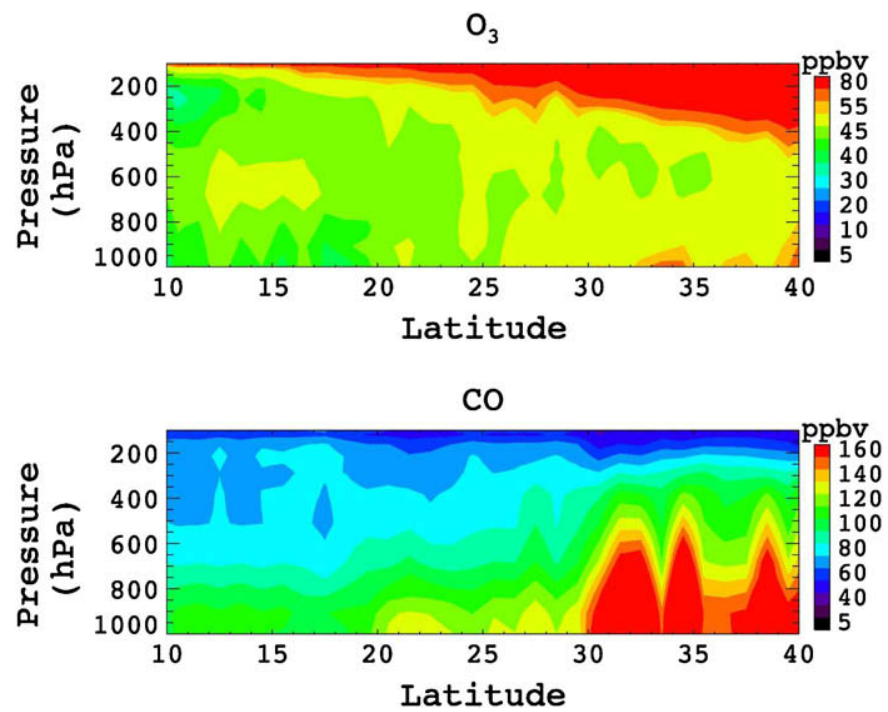

Fig. 7. Zonal mean concentration of TES $\mathrm{O}_{3}$ (upper) and $\mathrm{CO}$ (lower) between $\left(95^{\circ} \mathrm{W}-\right.$ $103^{\circ} \mathrm{W}$ ) in March 2006 

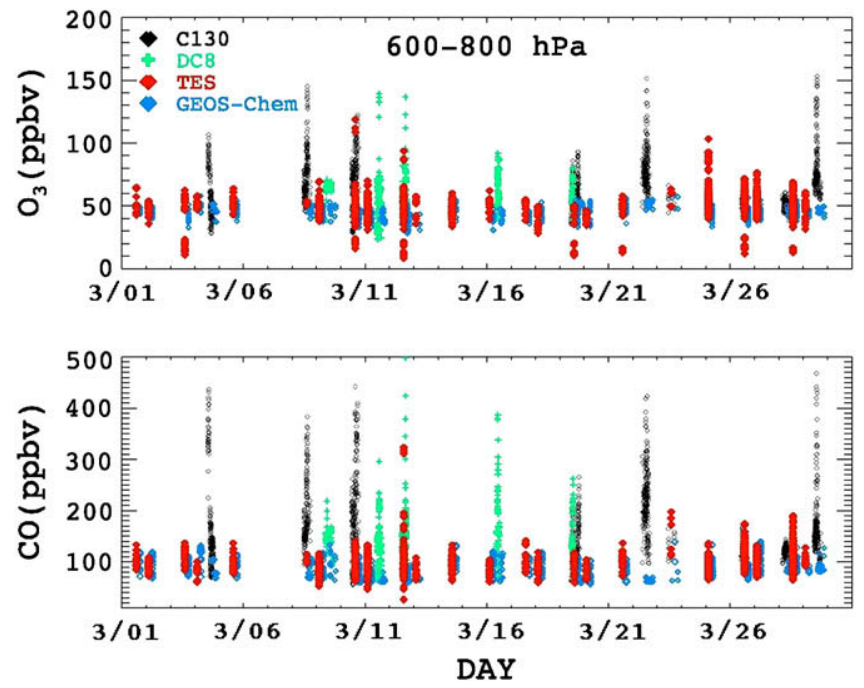

Fig. 8. Time series of individual $\mathrm{O}_{3}$ (upper panel) and $\mathrm{CO}$ (lower panel) data at 600 800 hPa over the MCMA and surrounding region (rectangle, Fig. 1) in March 2006. insitu observations from C-130 and DC-8, TES retrievals, and GEOS-Chem results are indicated by black diamonds and green cross, red, and blue diamonds, respectively. GEOS-Chem results are sampled along TES orbital and/or aircraft flight tracks (For interpretation of the references to color in this figure legend, the reader is referred to the web version of this article).

and CO concentrations reaching 100 ppbv and 300 ppbv, respectively. Six of the pollution events were observed by C-130 while four were observed by DC-8, again reflecting presumably C-130's tighter geographical coverage over the MCMA. On four of the strong pollution days, March 4th, 11th, 22nd, and 29th, there were no concurrent TES observations or no TES coverage. Note that the ranges of $\mathrm{O}_{3}$ and $\mathrm{CO}$ concentrations in Fig. 8 on any individual day are indicative of the spatial variabilities of $\mathrm{O}_{3}$ and $\mathrm{CO}$ considering the relatively large spatial coverage of the satellite and aircraft flight tracks (see Fig. 1). Fig. 8 shows that TES $\mathrm{O}_{3}$ shows to a large extent both the spatial and day-to-day variabilities over the MCMA regions (rectangle, Fig. 1). For example, enhanced $\mathrm{O}_{3}$ levels are seen in TES data on March 10th and 12th as in the in situ observations, as well as on March 25-27th when no in situ observations are available. TES CO, however, shows much less spatial and day-to-day variabilities compared with the in situ data.

GEOS-Chem results show little temporal variations in both $\mathrm{O}_{3}$ and $\mathrm{CO}$ and significant negative biases: $-15 \mathrm{ppbv}$ for $\mathrm{O}_{3}$ and -55 ppbv for $\mathrm{CO}$ in comparison with the in situ data. This may be in part due to the low $\mathrm{CO}$ emissions in the BRAVO inventory as $\mathrm{NO}_{x}$ emissions in the same inventory was found to be underestimated (Boersma et al., 2008). In addition, the model resolution at $2^{\circ} \times 2.5^{\circ}$ may be too coarse to capture the spatial variabilities seen in the in situ data. Further model analysis with finer horizontal resolutions would be helpful to understand the pollution and its outflow over the MCMA.

We take a closer look at the temporal mismatch between TES $\mathrm{O}_{3}$ and $\mathrm{CO}$ data and the in situ observations. An example is shown in Fig. 9 for March 10-12th, when both TES retrievals and the in situ observations were closest to the MCMA. There are large temporal and spatial variabilities in both $\mathrm{O}_{3}$ and $\mathrm{CO}$ during the course of the aircraft flights. The peaks in the in situ observations occurred after 13:00 local time due to the development of strong nocturnal vertical inversions over the MCMA (Velasco et al., 2007). TES data provide a snap shot at around 01:45 and 13:45 local time only, thus missing the intra-day temporal variability. However, TES data, especially $\mathrm{O}_{3}$, do show substantial spatial variability during the short period of overpass ( $\sim 20 \mathrm{~min}$ ) over the domain defined in
Fig. 1, comparable to those in the corresponding DC- observations. TES CO shows consistently lower variability. The implication of low $\mathrm{CO}$ variability for calculated TES $\mathrm{O}_{3}-\mathrm{CO}$ correlation will be discussed in the next section.

\section{4. $\mathrm{O}_{3}-\mathrm{CO}$ over the MCMA}

As discussed in the previous sections, TES captured little of the CO day-to-day variability at $600-800 \mathrm{hPa}$ during MILAGRO/INTEX$\mathrm{B}$ (Figs. 8 and 9). This would conceivably contribute to higher $\Delta \mathrm{O}_{3} /$ $\Delta \mathrm{CO}$ enhancement ratios. We examine in this section the $\mathrm{O}_{3}-\mathrm{CO}$ correlations and slopes for $600-800 \mathrm{hPa}$ derived from the aircraft measurements, TES retrievals, and GEOS-Chem results during MILAGRO/INTEX-B. The results are summarized in Table 1 and shown in Fig. 10. All the data are averages on $2^{\circ} \times 2.5^{\circ}$ grids over the domain defined in Fig. 1.

The in situ aircraft observations during MILAGRO/INTEX-B show a strong $\mathrm{O}_{3}-\mathrm{CO}$ correlation (correlation coefficient $R=0.78$ ) and a positive $\Delta \mathrm{O}_{3} / \Delta \mathrm{CO}$ enhancement ratio of $0.28 \mathrm{~mol} \mathrm{~mol}^{-1}$ for the domain defined in Fig. 1. The regression results were derived using the reduced major axis method (Hirsch and Gilroy, 1984). The slope is within the range of those derived from summertime in situ measurements over the Eastern U.S. at the surface and in the lower troposphere: $\Delta \mathrm{O}_{3} / \Delta \mathrm{CO}=0.2-0.4 \mathrm{~mol} \mathrm{~mol}^{-1}$ with $R=0.7-0.9$ (e.g., Chin et al., 1994; Parrish et al., 1993). In comparison, slopes derived from the International Consortium on Atmospheric Transport and Transformation (ICARTT) aircraft campaigns in July-August 2004 (Fehsenfeld et al., 2006; Singh et al., 2006) are $\Delta \mathrm{O}_{3} / \Delta \mathrm{CO}=0.31-$ $0.44 \mathrm{~mol} \mathrm{~mol}^{-1}$ with $R=0.5-0.67$ in the lower troposphere over the Eastern U.S. $\left(30^{\circ} \mathrm{N}-50^{\circ} \mathrm{N}, 50^{\circ} \mathrm{W}-100^{\circ} \mathrm{W}\right.$, and surface- $\left.600 \mathrm{hPa}\right)$. Previously, Zhang et al. (2006) reported a slope of $\Delta \mathrm{O}_{3}$ / $\Delta \mathrm{CO}=0.72 \mathrm{~mol} \mathrm{~mol}^{-1}$ derived from in situ aircraft measurements during the same ICARTT campaign over the Eastern U.S. The difference is that Zhang et al. (2006) excluded fresh pollution plumes $\left(\mathrm{NO}_{x} / \mathrm{NO}_{y}>0.4 \mathrm{~mol} \mathrm{~mol}^{-1}\right.$, altitude $<3 \mathrm{~km}$, and $\mathrm{HCN}>500$ pptv or $\left.\mathrm{CH}_{3} \mathrm{CN}>225 \mathrm{pptv}\right)$ and stratospheric influence $\left(\mathrm{O}_{3} /\right.$ $\left.\mathrm{CO}>1.25 \mathrm{~mol} \mathrm{~mol}^{-1}\right)$ within a smaller domain $\left(30^{\circ} \mathrm{N}-40^{\circ} \mathrm{N}, 70^{\circ} \mathrm{W}-\right.$ $80^{\circ} \mathrm{W}$, and $600-650 \mathrm{hPa}$ ). In comparison, following Zhang et al. (2006) except without excluding fresh pollution and stratospheric influence, the $\Delta \mathrm{O}_{3} / \Delta C O$ for the ICARTT campaigns is $0.55 \mathrm{~mol} \mathrm{~mol}^{-1}$, significantly lower than that reported by Zhang et al. (2006).
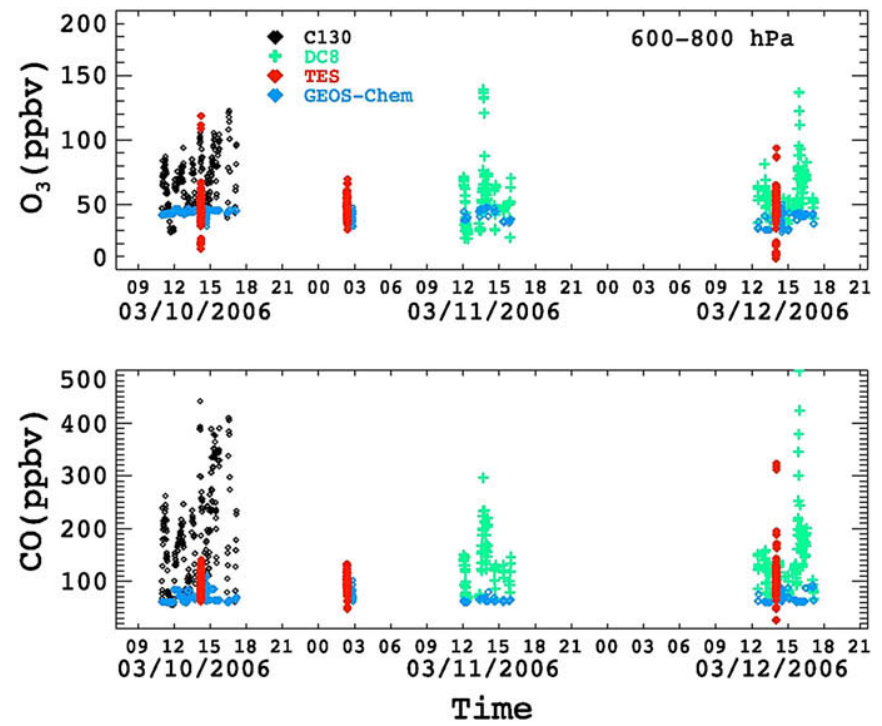

Fig. 9. Same as Fig. 7, but with diurnal variations for March 10-12th when both the insitu and TES samplings (Step and Stares) are closest to the MCMA (within $\sim 200 \mathrm{~km}$ ). 
Table 1

$\mathrm{O}_{3}-\mathrm{CO}$ correlation coefficient and slope $\left(\Delta \mathrm{O}_{3} / \Delta \mathrm{CO}\right)$.

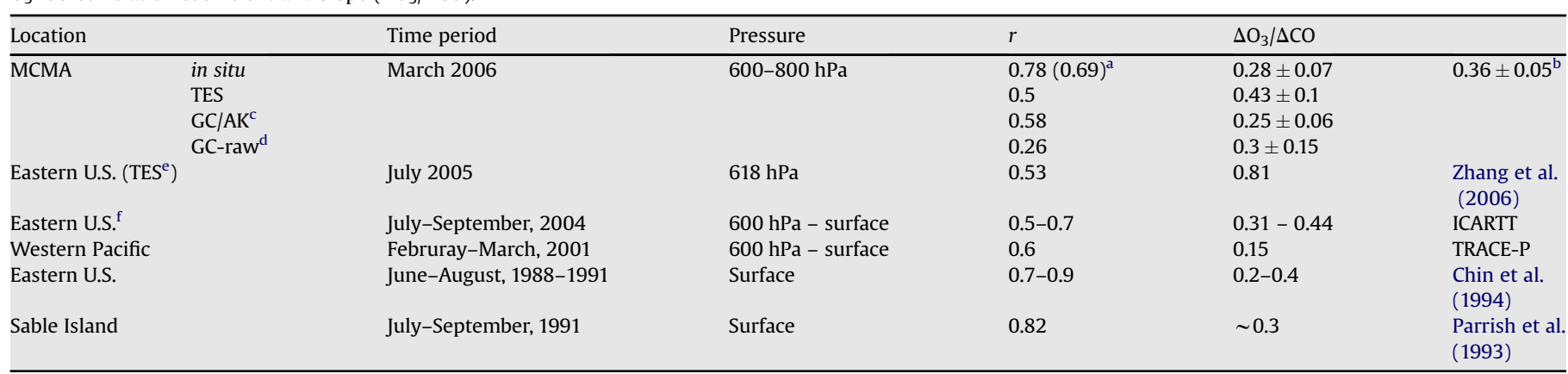

The data for this study were averaged onto $2^{\circ} \times 2.5^{\circ}$ grids over the MCMA (rectangle, Fig. 1 ).

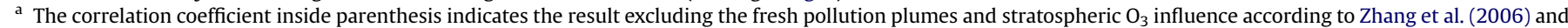
Hudman et al. (2007).

b The $\Delta \mathrm{O}_{3} / \Delta \mathrm{CO}$ derived from the same data as (a).

c GEOS-Chem results with TES averaging kernels applied.

d GEOS-Chem results without applying TES averaging kernels.

e TES version 1(V001) data.

${ }^{f}$ The data were selected from DC-8 between $30^{\circ} \mathrm{N}-50^{\circ} \mathrm{N}$ and $50^{\circ} \mathrm{W}-100^{\circ} \mathrm{W}$ without the filtering as (a).

TES $\mathrm{O}_{3}-\mathrm{CO}$ during MILAGRO/INTEX-B shows a correlation coefficient of $R=0.5$ and a slope of $\Delta \mathrm{O}_{3} / \Delta \mathrm{CO}=0.43 \mathrm{~mol} \mathrm{~mol}^{-1}$ for the domain defined in Fig. 1. The slope is significantly larger than that derived from the in situ data $\left(0.28 \mathrm{~mol} \mathrm{~mol}^{-1}\right)$. However, the slope from the in-situ data excluding fresh pollution and stratospheric influence is higher at $0.36 \mathrm{~mol} \mathrm{~mol}^{-1}$ (Table 1). As a comparison, Zhang et al. (2006) derived a TES $\Delta \mathrm{O}_{3} / \Delta \mathrm{CO}$ enhancement ratio of $0.81 \mathrm{~mol} \mathrm{~mol}^{-1}$ over the Eastern U.S. $\left(30^{\circ} \mathrm{N}-\right.$ $40^{\circ} \mathrm{N}, 70^{\circ} \mathrm{W}-80^{\circ} \mathrm{W}$ ) for July 2005 . Their calculations were done for TES data at $618 \mathrm{hPa}$ and within $10^{\circ} \times 10^{\circ}$ domains. Zhang et al.

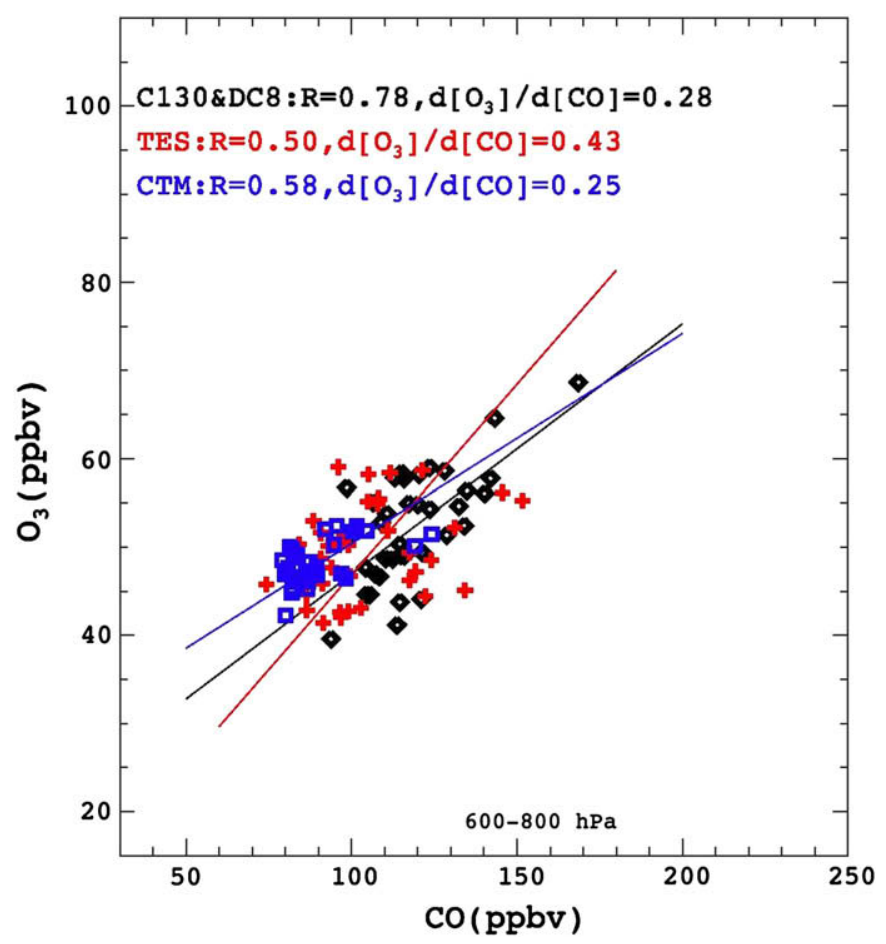

Fig. 10. $\mathrm{CO}-\mathrm{O}_{3}$ relationships at $600-800 \mathrm{hPa}$ during MILAGRO/INTEX-B (Phase I). insitu and TES data were averaged onto $2^{\circ} \times 2.5^{\circ}$ grids over the MCMA and surrounding region. Black diamonds - aircraft measurements; red crosses - TES; blue rectangles GEOS-Chem results sampled along TES orbital tracks with TES averaging kernels applied (For interpretation of the references to color in this figure legend, the reader is referred to the web version of this article).
(2006) noted that their slope of $0.81 \mathrm{~mol} \mathrm{~mol}^{-1}$ is comparable with the value of $0.72 \mathrm{~mol} \mathrm{~mol}^{-1}$ derived from the ICARTT in situ data when excluding fresh plumes and stratospheric influence. It is however significantly higher than the value of $0.55 \mathrm{~mol} \mathrm{~mol}^{-1}$ when not filtering out fresh plumes and stratospheric influence.

Whether fresh plumes and stratospheric influence should be filtered out in this type of comparisons between TES (and other space-borne instrument) versus aircraft observations remains a question. It is also important to note that a comparison between $\Delta \mathrm{O}_{3} / \Delta \mathrm{CO}$ slopes derived from TES retrievals and in situ aircraft observations may not be straightforward when the latter is not convoluted with TES averaging kernels. Model results, however, can be directly and straightforwardly compared with both in situ observations and TES data and therefore can be used as a transfer function between TES and in situ data. The GEOS-Chem $\Delta \mathrm{O}_{3} / \Delta C O$ enhancement ratios during MILAGRO/INTEX-B with and without TES averaging kernels applied show similar results, 0.25 versus $0.30 \mathrm{~mol} \mathrm{~mol}^{-1}$, respectively. The slopes are comparable with that derived from the in situ observations $\left(0.28 \mathrm{~mol} \mathrm{~mol}^{-1}\right)$ but much lower than that derived from TES data $\left(0.43 \mathrm{~mol} \mathrm{~mol}^{-1}\right)$. The higher slopes derived from TES data could be partly attributed to the lack of variability and a low bias in TES CO in the lower troposphere as we discussed in previous sections.

\section{Conclusions}

We examined $\mathrm{O}_{3}, \mathrm{CO}$, and their relationships from TES tropospheric retrievals (v003), aircrafts observations, and GEOS-Chem model results over the Mexico City Metropolitan Area (MCMA) and its surrounding regions $\left(15^{\circ} \mathrm{N}-30^{\circ} \mathrm{N}\right.$ and $\left.95^{\circ} \mathrm{W}-103^{\circ} \mathrm{W}\right)$ during the MILAGRO/INTEX-B campaigns. The MCMA pollution outflow occurs predominantly at $600-800 \mathrm{hPa}$ as evident in enhanced concentrations in $\mathrm{O}_{3}$ and $\mathrm{CO}$ in the aircraft observations. TES averaging kernels of $\mathrm{O}_{3}$ and $\mathrm{CO}$ have generally higher sensitivity at 600$800 \mathrm{hPa}$, but there is poor sensitivity over the Mexico City Basin $(\sim 750 \mathrm{hPa})$ due to retrieval issues. Thus TES data are mostly sensitive to the MCMA pollution outflow rather than pollution over the MCMA itself.

Direct comparison of absolute concentrations between in situ and TES data is difficult due to the spatiotemporal mismatches. Instead, we examined the spatial and temporal variability of TES $\mathrm{O}_{3}$ and $\mathrm{CO}$ data and $\mathrm{O}_{3}-\mathrm{CO}$ correlation. TES $\mathrm{O}_{3}$ exhibits to a large degree the spatial and day-to-day variability as see in the in situ 
observations. There is significantly smaller spatiotemporal variability in addition to a low bias in TES lower tropospheric CO compared with in situ observations over the MCMA and its surrounding regions. Both likely contribute to the apparent overestimate of TES $\Delta \mathrm{O}_{3} / \Delta \mathrm{CO}$ enhancement ratios during MILAGRO/ INTEX-B $\left(0.43 \mathrm{~mol} \mathrm{~mol}^{-1}\right)$ compared with that from the in situ data $\left(0.28 \mathrm{~mol} \mathrm{~mol}^{-1}\right)$. Thus the use of TES tropospheric $\mathrm{O}_{3}$ and $\mathrm{CO}$ retrievals for mapping continental pollution outflow needs further examination.

\section{Acknowledgements}

This work is performed at the Jet Propulsion Laboratory (JPL), California Institute of Technology, under contract with the NASA C. Shim and Q. Li were jointly supported by the JPL Research and Technology Development (R\&TD) program, Human Resources Development Fund (HRDF), NASA Atmospheric Composition Modeling and Analysis program (ACMAP), and the TES project at JPL. The GEOS-Chem model is managed at Harvard University with support from the NASA Atmospheric Chemistry Modeling and Analysis Program. We thank Melody Avery for the in-situ $\mathrm{O}_{3}$ measurements. We thank Lin Zhang for very helpful discussions.

\section{References}

Avery, M.A., Westberg, D.J., Fuelberg, H.E., et al., 2001. Chemical transport across the ITCZ in the central Pacific during an El Nino-Southern Oscillation cold phase event in March-April 1999. J. Geophys. Res. 106 (D23), 32,539-32,554. doi:10.1029/2001JD000728.

Beer, R., 2006. TES on the Aura Mission: scientific objectives, measurements and analysis overview. IEEE Trans. Geosci. Remote. Sens. 44, 1102-1105.

Beer, R., Glbavich, T.A., Rider, D.M., 2001. Tropospheric emission spectirometer for the Earth Observing System's Aura satellite. Appl. Opt. 40, 2356-2367.

Benkovitz, C.M., Scholtz, M.T., Pacyna, J., et al., 1996. Global gridded inventories of anthropogenic emissions for sulfur and nitrogen. J. Geophys. Res. 101 (D22), 29,239-29,253.

Bey, I., Jacob, D.J., Yantosca, R.M., et al., 2001. Global modeling of tropospheric chemistry with assimilated meteorology: model description and evaluation. J. Geophys. Res. 106 (D19), 23,073-23,096.

Boersma, K.F., Jacob, D.J., Bucsela, E.J., et al., 2008. Validation of OMI tropospheric $\mathrm{NO}_{2}$ observations during INTEX-B and application to constrain $\mathrm{NO}_{x}$ emissions over the eastern United States and Mexico. Atmos. Environ. 42, 4480-4497.

Bowman, K.W., Worden, J., Steck, T., et al., 2002. Capturing time and vertical variability of tropospheric ozone: a study using TES nadir retrievals. J. Geophys. Res. 107 (D23), 4723. doi:10.1029/2002JD002150.

Bowman, K.W., Rodgers, C.D., Kulawik, S.S., et al., 2006. Tropospheric emission spectrometer: retrieval method and error analysis. IEEE Trans. Geosci. Remote. Sens. 44, 1297-1307.

CAM, 1998. Preliminary Emissions Inventory; INE, 2000b, Almanaque de Datos y Tendencias de la Calidad del Aire en Ciudades Mexicanas, 2001.

Clerbaux, C., Edwards, D.P., Deeter, M., et al., 2008. Carbon monoxide pollution from cities and urban areas observed by the Terra/MOPITT mission. Geophys. Res. Lett. 35, L03817. doi:10.1029/2007GL032300.

Chameides, W.L., David, D.D., Rodgers, M.O., et al., 1987. Net ozone photochemical production over the eastern and central north Pacific as inferred from CTE/CITE 1 observations during fall 1983. J. Geosphys. Res. 92, 2131-2152.

Chin, M., Jacob, D.J., Munger, J.W., et al., 1994. Relationship of ozone and carbon monoxide over North America. J. Geophys. Res. 99, 14,565-14,573.

Duncan, B.N., Martin, R.V., Staudt, A.C., et al., 2003. Interannual and seasonal variability of biomass burning emissions constrained by satellite observations. J. Geophys. Res. 108 (D2), 4100. doi:10.1029/2002JD002378.

Epa, U.S., 2004. EPA Clearinghouse for inventories and emissions factors: 1999 National Emission Inventory Documentation and Data - final version 3.0. Available from: http://www.epa.gov/ttn/chief/net/1999inventory.html.

Fast, J.D., de Foy, B., Acevedo Rosas, F., et al., 2007. A meteorological overview of the MILAGRO field campaigns. Atmos. Chem. Phys. 7, 2233-2257.

Fehsenfeld, F.C., et al., 2006. International Consortium for Atmospheric Research on Transport and Transformation (ICARTT): North America to Europe - overview of the 2004 summer field study. J. Geosphys. Res. 111, D23S01. doi:10.1029/ 2006JD007829.

Fishman, J., Seiler, W., 1983. Correlative nature of ozone and carbon monoxide in the troposphere: implications for the tropospheric ozone budget. J. Geosphys. Res. 88, 3662-3670.

Fuchs, R.J., Brennan, E., Chamie, J., et al., 1994. Mega-City Growth and the Future. United Nations University Press, Tokyo.
Guenther, A.B., Karl, T., Harley, P., et al., 2006. Estimates of global terrestrial isoprene emissions using MEGAN (Model of Emissions of Gases and Aerosols from Nature). Atmos. Chem. Phys. 6, 3181-3210.

Hirsch, R.M., Gilroy, E.J., 1984. Methods of fitting a straight line to data: examples in water resources. Water Resour. Bull., 20,705-20,711.

Hudman, R.C., Jacob, D.J., Turquety, S., et al., 2007. Surface and lightning sources of nitrogen oxides over the United States: magnitudes, chemical evolution, and outflow. J. Geophys. Res. 112, D12S05. doi:10.1029/2006JD007912.

Ipcc, 2007. "Forth Assessment Report: Climate Change 2007", Intergovernmental Panel on Climate Change. Available from: http://www.ipcc.ch/ipccreports/ assessments-report.html.

Jones, D.B.A., Bowman, K.W., Palmer, P.I., et al., 2003. Potential of observations from the Tropospheric Emission Spectrometer to continental sources of carbon monoxide. J. Geophys. Res. 108 (D24), 4789. doi:10.1029/2003JD003702.

Jourdain, L., Worden, H.M., Worden, J.R., et al., 2007. Tropospheric vertical distribution of tropical Atlantic ozone observed by TES during the northern African biomass burning season. Geophys. Res. Lett. 34, L04810. doi:10.1029/2006GL028284.

Kuhns, H., Knipping, E.M., Vukovich, J.M., et al., 2005. Development of a United StatesMexico Emissions Inventory for the Big Bend Regional Aerosol and Visibility Observational (BRAVO) Study. J. Air. Waste Manag. Assoc. 55 (5), 677-692.

Kulawik, S.S., Worden, J., Eldering, A., et al., 2006. Implementation of cloud retrievals for Tropospheric Emission Spectrometer (TES) atmospheric retrievals: part 1 . Description and characterization of errors on trace gas retrievals. J. Geophys. Res. 111, D24204. doi:10.1029/2005JD006733.

Li, Q., Jacob, D., Park, R., et al., 2005. North American pollution outflow and the trapping of convectively lifted pollution by upper-level anticyclone. J. Geophys. Res. 110 D10301.

Logan, J.A., Prather, M.J., Wofsy, S.C., et al., 1981. Tropospheric Chemistry: a global perspective. J. Geophys. Res. 86, 7210-7254.

Lopez, J.P., Luo, M., Christensen, L.E., et al., 2008. TES carbon monoxide validation during two AVE campaigns using the Argus and ALIAS instruments on NASA's WB-57F. J. Geophys. Res. 113, D16S47. doi:10.1029/2007JD008811.

Luo, M., Rinsland, C.P., Rodgers, C.D., et al., 2007a. Comparison of carbon monoxide measurements by TES and MOPITT: the influence of a priori data and instrument characteristics on nadir atmospheric species retrievals. J. Geophys. Res. 112, D09303. doi:10.1029/2006JD007663.

Luo, M., Rinsland, C., Fisher, B., et al., 2007b. TES carbon monoxide validation with DACOM aircraft measurements during INTEX-B 2006b. J. Geophys. Res. 112, D24S48. doi:10.1029/2007JD008803.

Madronich, S., Flocke, F., Orlando, J., et al., 2004. MIRAGE-Mex: Mexico City pollution outflow experiment: science overview document. Available from: http:// mirage-mex.acd.ucar.edu/Documents/MIRAGE-Mex_SOD_040324.pdf

Mage, D., Ozolins, G., Peterson, P., et al., 1996. Urban air pollution in megacities of the world. Atmos. Environ. 30 (5), 681-686.

Massie, S.T., Gille, J.C., Edwards, D.P., et al., 2006. Satellite observations of aerosol and CO over Mexico city. Atmos. Environ. 40, 6019-6031.

Molina, L.T., Molina, M.J., 2002. Air Quality in the Mexico Megacity. Kluwer Academic Publishers, Norwell, M.A.

Molina, M.J., Molina, L.T., 2004. Critical review: megacities and atmospheric pollution. J. Air and Waste Manage. Assoc. 54 (6), 644-680.

Olivier, J.G.J., Berdowski, J.J.M., 2001. Global emissions sources and sinks. In: Berdowski, J., Guicherit, R., Heij, B.J. (Eds.), The Climate System. A.A. Balkema Publishers/Swets \& Zeitlinger Publishers, Lisse, The Netherlands, ISBN 905809 255 0, pp. 33-78.

Osterman, G., Bowman, K., Cady-Pereira, K., et al., 2006. Tropospheric emission spectrometer (TES) validation report, JPL D33192, version 2.0. Available from: http://tes.jpl.nasa.gov/docsLinks/documents.ctm.

Parrish, D.D., Holloway, J.S., Trainer, M., et al., 1993. Export of North American ozone pollution to the North Atlantic Ocean. Science 259, 1436-1439.

Richards, N.A.D., Osterman, G.B., Browell, E.V., et al., 2008. Validation of Tropospheric Emission Spectrometer (TES) ozone profiles with aircraft observations during INTEX-B. J. Geophys. Res. 113, D16S29. doi:10.1029/2007JD008815.

Rogers, C.D., 2000. Inverse Methods for Atmospheric Sounding: Theory and Practice. World Sci, River Edge, N.J.

Sachse, G.W., Hill, G.F., Wade, L.O., et al., 1987. Fast-response, high-precision carbon monoxide sensor using a tunable diode laser absorption technique. J. Geophys. Res. 92, 2071-2081.

Singh, H.B., Brune, W.H., Crawford, J.H., et al., 2006. Overview of the summer 2004 Intercontinental Chemical Transport Experiment - North America (INTEX-A). J. Geophys. Res. 111, D24S01. doi:10.1029/2006JD007905.

Singh, H.B., Brune, W.H., Crawford, J.H., et al. An overview of the INTEX-B campaign: transport and transformation of pollutants over the Pacific and the Gulf of Mexico. Atmos. Chem. Phys. Discuss., submitted.

Velasco, E., Marquez, C., Bueno, E., et al., 2007. Vertical distribution of ozone and VOCs in the low boundary layer of Mexico City. Atmos. Chem. Phys. Discuss. 7, 12751-12779.

Worden, H.M., Logan, J.A., Worden, J.R., et al., 2007. Comparisons of Tropospheric Emission Spectrometer (TES) ozone profiles to ozonesodes: methods and initial results. J. Geophys. Res. 112, D03309. doi:10.1029/2006JD007258.

Worden, J., Kulawik, S.S., Shephard, M.W., et al., 2004. Predicted errors of tropospheric emission spectrometer nadir retrievals from spectral window selection. J. Geophys. Res. 109, No. D9, D09308. doi:10.1029/2004JD004522.

Zhang, L., Jacob, D.J., Bowman, K.W., et al., 2006. Ozone-CO correlations determined by the TES satellite instrument in continental outflow regions. Geophys. Res. Lett. 33, L18804. doi:10.1029/2006GL026399. 